\title{
PENGARUH TAX AMNESTY, PERTUMBUHAN EKONOMI, KEPATUHAN WAJIB PAJAK TERHADAP PENERIMAAN PAJAK DI KPP PRATAMA PEKANBARU TAMPAN
}

\author{
Ari Nur Wahidah \\ Dosen Fakultas Ekonomi dan Ilmu Sosial \\ Universitas Islam Negeri Sulthan Syarif Kasim Riau \\ email: arie05alfa@gmail.com
}

\begin{abstract}
Abstrak
Penelitian ini bertujuan untuk membuktikan secara empiris pengaruh tax amnesty, pertumbuhan ekonomi kepatuhan wajib pajak, terhadap penerimaan pajak. Penelitian ini merupakan penelitian kuantitatif dengan menggunakan data primer yang diperoleh dari kuesioner dan diukur dengan menggunakan skal likert. Populasi penelitian ini adalah wajib pajak orang pribadi (WP) yang terdaftar dikantor pelayanan pajak pratama pekanbaru Tampan sebanyak 100 orang. Metode pemilihan sampel menggunakan incidental sampling, yaitu siapa yang secara kebetulan bertemu dengan peneliti digunakan sebagai sampel serta cocok sebagai sumber data. Tehnik analisis data yang digunakan adalah analisis regresi linear berganda dengan menggunakan SPSS 17.0 for Windows. Hasil penelitian menunjukkan bahwa secara parsial dan simultan tax amnesty, pertumbuhan ekonomi, kepatuhan wajib pajak berpengaruh positif dan signifikan terhadap penerimaan pajak.
\end{abstract}

Kata Kunci : tax amnesty, ekonomi , pajak, tranformasi kelembagaan

\section{PENDAHULUAN}

Kita tahu bahwa pembangunan nasional yang berlangsung secara terusmenerus dan berkesinambungan selama ini bertujuan untuk meningkatkan kesejahteraan rakyat. Namun, untuk merealisasikan tujuan tersebut diperlukan suatu anggaran pembangunan yang cukup besar. Salah satu usaha untuk mewujudkan peningkatan penerimaan untuk pembangunan tersebut adalah dengan menggali sumber dana yang berasal dari dalam negeri, yaitu pajak.

Pajak merupakan sumber pendapatan Negara yang sangat penting Pajak merupakan sumber penerimaan yang dominan dalam struktur Anggaran Pendapatan dan Belanja Negara (APBN). Hampir 70 persen penerimaan berasal dari sektor pajak. Karena itu untuk mencapai target penerimaan negara dari sektor perpajakan dibutuhkan upaya-upaya yang nyata, serta mengimplementasikan dalam bentuk kebijakan pemerintah. Salah satunya adalah tax amnesty atau pengampunan pajak. Kebijakan ini diharapkan dapat meningkatkan subyek pajak maupun obyek pajak.Subyek pajak dapat berupa kembalinya dana-dana yang berada di luar negeri, sedangkan dari sisi obyek pajak berupa penambahan jumlah wajib pajak. Sebenarnya Indonesia pernah menerapkan amnesti pajak pada 1984. Namun pelaksanaannya tidak efektif karena wajib pajak kurang merespons dantidak diikuti dengan reformasi sistem administrasi perpajakan secara menyeluruh. Pengampunan pajak diharapkan menghasilkan penerimaan pajak yang selama ini belum atau kurang bayar, disamping meningkatkan kepatuhan membayar pajak karena makin efektifnya pengawasan, didukung semakin akuratnya informasi mengenai daftar kekayaan wajib pajak 
Menurut UU Tax Amnesty No 11 tahun 2016 Pengampunan Pajak (Tax Amnesty) adalah pengampunan atau pengurangan pajak terhadap property yang dimiliki oleh perusahaan dalam bentuk penghapusan pajak terutang, penghapusan sanksi pajak terutang, penghapusan sanksi pidana tertentu yang harus diharuskan membayar dengan uang tebusan. Menurut UU Tax Amnesty No 11 tahun 2016 wajib pajak adalah Wajib Pajak adalah orang pribadi atau badan yang mempunyai hak dan kewajiban perpajakan sesuai dengan ketentuan peraturan perundang-undangan di bidang perpajakan. Secara umum, setiap wajib pajak yang belum menunaikan kewajiban perpajakannya diperbolehkan untuk berpartisipasi dalam program tax amnesty. Artinya, program tax amnesty ini ditujukan kepada wajib pajak yang telah berada dalam sistem administrasi perpajakan dan wajib pajak yang belum masuk dalam sistem administrasi perpajakan. Perlakuan yang berbeda dimungkinkan ketika wajib pajak yang hendak berpartisipasi dalam program tax amnesty telah diperiksa atau sedang dalam proses pemeriksaan. Dalam hal ini, wajib pajak yang telah diperiksa atau sedang dalam proses pemeriksaan tersebut tidak diperbolehkan berpartisipasi dalam program tax amnesty karena jumlah tunggakan pajaknya telah diketahui oleh otoritas pajak. Wajib pajak juga dapat diberikan pengampunan jika ketentuan peraturan perundang-undangan menyatakan wajib pajak yang mengungkapkan kewajiban perpajakan atau harta kekayaannya secara sukarela berhak mendapatkan penurunan atau penghapusan sanksi administrasi.

Tax amnesty adalah suatu kesempatan waktu yang terbatas pada kelompok pembayar pajak tertentu untuk membayar sejumlah tertentu dan dalam waktu tertentu berupa pengampunan kewajiban pajak (termasuk bunga dan denda) yang berkaitan dengan masa pajak sebelumnya atau periode tertentu tanpa takut hukuman pidana. Ini biasanya berakhir ketika otoritas yang dimulai penyelidikan tanpa pajak pajak masa lalu. Dalam beberapa kasus, undang undang amnesty yang memperpanjang juga membebankan hukuman yang lebih berat pada mereka yang memenuhi syarat untu amnesty tetapi tidak mengambilnya.

Kebijakan tax amnesty sebenarnya pernah dilakukan di Indonesia pada tahun 1984. Demikian juga kebijakan lain yang serupa berupa sunset policy telah dilakukan pada tahun 2008. Sejak program sunset policy di implementasikan sepanjang tahun 2008 telah berhasil menambah jumlah NPWP baru sebanyak 5.653.128 NPWP, bertambbahnya SPT tahunan sebanyak 804.814 SPT dan bertambahnya penerimaan $\mathrm{PPh}$ Sebesar Rp7,46 Trilyun. Jumlah NPWP orang pribbadi 15,07 juta, NPWP bendaharawan 447.000. dan NPWP badan hokum 1,63 juta. Jadi totalnya 17,16 juta (Data DJP.2010 kuartal 1)

Tabel 1. Anggaran Penerimaan Negara dalam APBN 2015

\begin{tabular}{|l|r|r|}
\hline \multicolumn{1}{|c|}{ Uraian } & $\begin{array}{c}\text { Jumlah } \\
\text { (dalam } \\
\text { Trilyun } \\
\text { Rupiah) }\end{array}$ & Presentase \\
\hline Pajak & 1.489 .3 & $83,0 \%$ \\
\hline $\begin{array}{l}\text { Pendapatan } \\
\text { Negara bukan } \\
\text { pajak }\end{array}$ & 269.1 & $15,0 \%$ \\
\hline Hibah & 3.3 & $0,2 \%$ \\
\hline Total & 1.793 .6 & $100 \%$ \\
\hline
\end{tabular}

Sumber : Kementrian Keuangan Republik Indonesia, 2015

Data pada table 1 menunjukkan bahwa penerimaan Negara dari sector pajak memberikan konntribusi sebesar $83 \%$ pada keseluruhan anggaran penerimaan Negara atau senilai Rp 1.489,3 Trilyun. Penerimaan pajak dalam APBN 2015 sebesar Rp 1489,3 Trilyun merupakan peningkatan sebesar 29,9\% dibandingkan realisasi penerimaan pajak tahun 2014 seperti tampak pada table 2 
Tabel 2. Perkembangan penerimaan pajak dari tahun 2010-1015

\begin{tabular}{|r|r|r|r|}
\hline Tahun & $\begin{array}{c}\text { Jumlah } \\
\text { Dalam } \\
\text { Trilyun } \\
\text { Rupiah }\end{array}$ & $\begin{array}{c}\text { Kenaikan } \\
\text { (Dalam } \\
\text { Trilyun } \\
\text { Rupiah) }\end{array}$ & $\begin{array}{c}\text { Persentase } \\
\text { Kenaikan }\end{array}$ \\
\hline 2010 & 649,0 & - & - \\
\hline 2011 & 837,9 & 188,8 & $20,8 \%$ \\
\hline 2012 & 980,15 & 142,6 & $12,2 \%$ \\
\hline 2013 & $1.077,3$ & 96,8 & $9,9 \%$ \\
\hline 2014 & $1.146,5$ & 69,2 & $9,9 \%$ \\
\hline 2015 & $1.489,3$ & 342,8 & $29,9 \%$ \\
\hline
\end{tabular}

Sumber : Kementrian Keuangan Republik Indonesia, 2015

Data pada table 2 menunjukkan bahwa kenaikan penerimaan pajak sebesar $29,9 \%$ merupakan kenaikan target penerimaan pajak terbesar dalam 5 tahun terakhir. Kenaikan target menjalankan kebijakan pemerintah yang baru. Pemerintahan yang baru mempunyai beberapa program baru yakni, Kartu Indonesia Sehat, Kartu Indonesia Pintar, alokasi dana desa, dan peningkatan pembangunan infrastruktur. Hingga tanggal 31 Desember 2015 realisasi penerimaan pajak nasional tercapai sebesar Rp 1.155 trilyun atau $89 \%$ dari target penerimaan pajak dalam APBN 2015. Pemerintah harus dapat mencapai target penerimaan pajak yang ditetapkan. Apabila pemerintah gagal dalam mencapai target penerimaan pajak, maka akan menyebabkan kegagalan mengelola APBN 2015 yang akan berpengaruh terhadap pengelolaan APBN tahun berikutnya. Kegagalan mencapai target penerimaan APBN 2015 akan berdampak pada bertambahnya deficit utang pada APBN tahun 2016.

\section{LANDASAN TEORI}

\subsection{Tarif dan Utang Pajak}

Secara teori pemungutan pajak tidak terlepas dari rasa keadilan, sebab keadilan dapat menciptakan keadilan keseimbangan social yang sangat penting untuk kesejahteraan masyarakat, dalam penetapan tarifnya pun harus berdasarkan pada prinsip prinsip keadilan. Dalam penghitungan pajak yang terutang digunakan tarif pajak. Tariff pajak yang dimaksud adalah tariff untuk menghitung besarnya pajak yang terutang (pajak yang harus dibayar) besarnya tariff pajak dapat dinyatakan dalam persentase.

Apabila melihat timbulnya utang pajak, bahwa utang pajak timbul karena adanyasurat keputusan pajak (ajaran formal), perbedaan dengan ajaran materil bahwa utang pajak timbul karena undang undang. Ajaran ini diterapkan pada self assessment system. Hapusya utang pajak disebabkan antara lain :

1. Pembayaran

Utang pajak yang melekat pada Wajib Pajak akan dihapus karena pembayaran yang dilakukan ke Kas Negara

2. Kompensasi

Keputusan yang ditunjukkan kepada kompensasi utang pajak dengan tagihan seseorang diluar pajak tidak diperkenankan. Oleh karena itu kompensasi terjadi apabila Wajib Pajak mempunyai tagihan berupa kelebihan pembayaran pajak. Jumlah kelebihan pembayaran pajak yang diterima Wjib Pajak seblumnya harus dikompensasikan dengan pajak-pajak yang terutang.

3. Daluwarsa

Daluwarsa diartikan sebagai daluwarsa penagihan. Hak untuk melakukan penagihan. Hak untuk melakukan penagihan pajak. Daluwarsa setelah lampau waktu sepuluh tahun terhitung sejak saat terutangnya pajak atau berakhirnya masa pajak, bagian tahun pajak atau tahun pajak yang bersangkutan. Hal ini untuk memberikan kepastian hokum kapan uang pajak tidak dapat ditagih lagi. Namun daluwarsa penagihan pajak tertangguh, antara lain apabila diterbitkan Surat Teguran dan Surat Paksa

4. Pembebasan

Utang pajak tidak berakhir dalam arti yang semestinya tetapi karena ditiadakan. Pembebasan pada umumnya tidak diberikan terhadap pokok 
pajaknya, tetapi diberikan terhadap sanksi administrasinya.

5. Penghapusan

Penghapusan utang pajak ini sama halnya dengan pembebasan, tetapi diberikan karena keadaan keuangan Wajib Pajak

\subsection{Penerapan Tax Amnesty sebagai alternatif}

Bagi banyak Negara, pengampunan pajak (tax amnesty) seringkali dijadikan alat untuk menghimpun penerimaan Negara dari sector pajak (tax revenue) secara cepat dalam jangka waktu yang relative singkat. Program tax amnesty ini dilaksanakan karena semakin parahnya upaya penghindaran pajak. Kebijakan ini dapat memperoleh manfaat perolehan dana, terutama kembalinya dana yang disimpan di luar negri, dan kebijakan ini dalam mempunyai kelemahan dalam jangka panjang dapat berakibat buruk berupa menurunnya kepatuhan sukarela (voluntary compliance) dari wajib pajak patuh, bilamana tax amnesty dilaksanakan dengan program yang tidak tepat. Tulisan ini memberikan gambaran mengenai pelaksanaan tax amnesty dibeberapa Negara yang relative lebih berhasil dalam melaksanakan kebijakan pengampunan pajak seperti di Afrika Selatan, Irlandia dan India, dengan maksud untuk mempelajari kebijakan dari masing-masing Negara serta menganalisis factor-faktor yang menyebabkan program ini dapat berhasil dan mencapai target yang ditetapkan seta perpspektifnya bagi pebisnis Indonesia.

Berdasarkan penelitian (Enste \& Schneider, 2002), bahwa besarnya persentase kegiatan ekonomi bawah tanah (undeground economic) dinegara maju dapat mencapai 14-16 \% dari produk domestic bruto (PDB) sedangkan dinegara berkembang mencapai 34-44 \% dari PDB. Kegiatan ekonomi bawah tanah ini tidak pernah di laporkan sebagai penghasilan dalam formulir surat pemberitahuan tahuan (SPT) pajak penghasilan, sehingga masuk dalam criteria penyelundupan pajak (tax evasion).
Penyelundupan pajak mengakibatkan beban pajak yang harus dipikul oleh para beban pajak yang harus dipikul oleh para wajib pajak yang jujur membayar pajak menjadi lebih berat, dalam hal ini mengakibatkan ketidak adilan yang tinggi. Peningkatan kegiatan ekonomi bawah tanah yang dibarengi dengan penyelundupan pajak saat ini sangat merugikan Negara karena berarti hilangyanya penerimaan pajak yang sangat dibutuhkan untuk membiayai program pendidikan, kesehatan dan program -program pengentasan kemiskinan lainnya. Oleh sebab itu timbulnya pemikiran untuk mengenakan kembali pajak yang belum dibayar dari kegiatan ekonomi bawah tanah tersebut melalui program khusus yakni pengampunan pajak (tax amnesty)

\subsection{Peluang dan Tantangan \\ Implementasi Tax Amnesty di Indonesia}

Ada beberapa langkah yang ditempuh pemerintah Indonesia khususnya Direktorat Jendral Pajak guna meningkatkan penerimaan Negara dari sector pajak. Antara lain melaksanakan program Sensus Pajak Nasional.selain itu melakukan penyempurnaan peraturan untuk menangani tindakan penghindaran pajak (tax avoidance) tindakan penggelapan pajak melalui transfer pricing dan pengenaan pajak final.

Langkah lainnya adalah pembenahan internal aparatur dan system perpajakan. Demikian juga akan dilakukan kenaikan tariff cukai tembakau mulai tahun 2012 yang rata-rata sebesar $12.2 \%$. Upaya berikutnya adalah akan dilakukan peningkatan akurasi penelitian nilai pabean dan klasifikasi barang impor serta peningkatan evektivitas pemeriksaan fisik barang. Termasuk penyempurnaan implementasi Indinesia Nasional Single Windows (INWS) serta pengembangan pelayanan di bidang kepabeanan dan cukai.

Selain itu salah satu bentuk upaya atau inovasi lain dalam system perpajakan yang berguna meningkatkan penerimaan pajak tanpa menambah beban baik jenis 
pajak baru maupun persentase pajak yang sudah ada kepada masyarakat, dunia usaha dan para pekerja adalah melalui program tax amnesty, salah satu tujuan pengampunan pajak ini diharapkan dapat mengurangi citra negative pada aparat perpajakan yang selalu dipersepsikan selalu bersikap sewenang-wenang dan harus selalu dihindari, dan berubah menjadi hubungan yang lebih menyenangkan. Pada dasarnya inovasi atau upaya ini dapat diterapkan di Indonesia.

Keunggulan yang diharapkan bila kebijakan tax amnesty diimplementaikan yaitu akan dapat mendorong masuknya dana-dana dari luar negri yang dalam jangka panjang dapat digunakan sebagai pendorong investasi sebagai pendorong investasi yang pada gilirannya bermanfaat untuk menstimulasi perekonomian nasional.

Di sisi lain kelemahannya bila diterapkan pengampunan pajak adalah tidak serta merta menjamin peningkatan kinerja setoran pajak ke kas Negara. Hal ini bisa sebaliknya berpotensi terjadinya penyelewengan, manipulasi dan tindakan moral hazard lainnya. Para pengusaha yang memperoleh pemutihan pajak akan melakukan penggelapan kewajiban pajaknya. Kecuali bila diberlakukan pengampunan pajak bersyarat, wajib pajak harus transparan terhadap asset asset dan penghasilan merekan. Hal ini guna menghindari kekeliruan yang sama yang terjadi ditahun 1984 tidak terulang kembali yaitu minimnya akses informasi terhadap masyarakat dan minimnya keterbukaan/transparansi serta sosialisasi kebijakan ini.

\subsection{Analisis SWOT Implementasi Tax Amnesty}

Bila digunakan analisis SWOT, terutama dilihat dari sisi kekuatan,kelemhan,peluang dan tantangan implementasi penerapan Tax Amnesty, dapat dijelaskan sebagai berikut:

\subsubsection{Strenght (Kekuatan)}

1. Sumber daya yang dimiliki pada instansi aparatur pajak saat ini sudah memadai yang dapat mendukung diberlakukannya penerapan tax amnesty. Demikian juga infrastruktur pendukung lainnya. Tercatat pegawai Ditjen Pajak saat ini adalah sebesar 32.000 0rang, sehingga bila wajib pajak saat ini berjumlah 20 juta orang berarti rasionya adalah $1: 625$ walaupun kedepan perlu ditambah lagi mengingat setiap tahunnya wajib pajak mengalami peningkatan.

2. Bila kebijakan perpajakan seperti tax amnesty diterapkan maka akan meningkatkan menciptakan kerelaan masyarakat untuk mendaftarkan diri menjadi Wajib Pajak dan menunaikan kewajiban perpajakannya seperti yang dilakukan pemerintah sebelumnya dengan program sunset policy maupun pembebasan pajak fiscal bagi warga negar Indonesia yang hendak bepergian ke luar negri dengan syarat memiliki Nomor Pokok Wajip Pajak.

3. Kondisi ekonomi social saat ini relative stabil dengan rata rata pertumbuhan ekonomi saat ini di atas 5\% hal ini dapat menjamin pemberlakuan tax amnesty. Beberapa Negara lain termasuk Afrika Selatan, Korea Selatan dan lain-lain, memberlakukan tax Amnesty pada saat ekonomi Negara tersebut dalam kondisi stabil.

\subsubsection{Weakness (Kelemahan)}

1. Tidak mempunyai payung hokum yang dapat menjadi landasan hukum implementasi tax amnesty yang dapat memberikan aturan jelas. Hal ini akan menambah keraguan bagi wajib pajak dan calon wajib pajak. Namun apabila implementasi tax amnesty akan diterapakan maka berarti harus dibuat terlebih dahulu peraturan perpajakan (undang-undang) yang mengatur tentang hal itu. Hal ini tentu saja akan memakan waktu yang lebih lama karena tentu saja harus mendapat persetujuan dari DPR.

2. Reformasi dan penataan system perpajakan sedang dilakukan baik perbaikan potensi, intensifikasi dan ekstensifikasi, pengembangan tehnologi informasi, perbaikan sumber daya 
manusia serta pengawasan. Oleh karena itu bila tax amnesty dilakukan maka hasilnya tidak optimal. Idealnya tax amnesty dilakukan hanya sekali

\subsubsection{Opportunity (Peluang)}

1. Program ini diharapkan dapat meningkatkan dana-dana masuk ke Indonesia yang cukup banyak disimpan diluar negri. Disamping itu dana-dana yang selama ini diparkir diluar negri dapat kembali masuk ketanah air bila pemerintah secepatnya menerapkan pengampunan pajak.

2. Sejumlah Negara telah sukses memberlakukan tax amnesty salah satu diantaranya Afrika Selatan, Korea Selatan dan India

1. Tingkat kepercayaan masyarakat yang masih tinggi merupakan salah satu peluang untuk mewujudkan tujuan akhir guna mengamankan penerimaan Negara dari sector pajak.

2. Kondisi ekonomi Indonesia selama ini yang selalu membaik memberikan kesempatan untuk dapat diterapkannya kebijakan tax amnesty

\subsubsection{Treat (Tantangan)}

1. Salah satu tantangan yang dihadapi Ditjen Pajak adalah antara lain terus dikembangkannya hubungan kerjasama Internasional baik dengan institusi Negara-negara lain maupun lembaga keuangan internasional untuk dapat saling tukar menukar data dan informasi perpajakan.

2. Beberapa peristiwa penyimpangan di Ditjen pajak seperti kasus Gayus Tambunan berakibat pada penggiringan opini wajib pajak untuk memboikot pembayaran pajak dengan cara penghindaran pajak.

3. Banyaknya permasalahan yang timbul terkait pengampunan pajak sehingga aturannyapun menjadi lebih kompleks oleh karenanya di perlukan aturan yang jelas yang tidak menimbulkan persepsi yang berbeda serta berbagai kepentingan
2.5. Beberapa hal penting menjadi yang menjadi acuan implementasi tax amnesty di Indonesia

1. Penelitian dan pengumpulan data sebelum pelaksanaan program pengampunan pajak sangat diperlukan

2. Optimalisasi strategi "pull and Push"

3. Mendefinisikan dan mengkomunikasikan maksud dan tujuan dari program secara tepat dan baik

4. Mendapatkan persetujuan dan komitmen yang kuat dari seluruh jajaran organisasi

5. Mendapatkan persetujuan dan dukungan yang kuat dari parlemen

6. Tidak melakukan perubahan persyaratan administrasi ditengah jalan misalnya perubahan dokumen bentuk dan isi formulir

7. Meminimalisasi persyaratan yang sifatnya kurang jelas

8. Melibatkan kalangan profesioanl sebanyak mungkin seperti akuntan,pengacara, konsultan pajak, dunia perbankan dll

9. lakukan program sosialisasi keseluruh lapisan masyarakat luas dengan strategi yang tepat

10. penerapan pengampunan pajak ini harus menjadi bagian dari reformasi perpajakan dan bukan terpisah, yang dapat berdampak pada kontraproduktif

\subsection{Tingkat Kepatuhan Wajib Pajak di Indonesia}

Tingkat kepatuhan WP (tax coverage) memegang peranan penting terhadap keberhasilan pemerintah dalam menetukan besarnya penerimaan dari sector pajak. Direktorat Jendaral Pajak mencatat rasio kepatuhan Wajib Pajak (WP) dalam menyampaikan Surat Pemberitahuan (SPT) Tahunan dapat dilhat dari Tabel 1. Sebagai berikut : 
Tabel 3. Tingkat Kepatuhan WP tahun 2013-2015

\begin{tabular}{|l|l|l|l|l|}
\hline Tahun & $\begin{array}{c}\text { Tingkat } \\
\text { Kepatuhan(\%) }\end{array}$ & $\begin{array}{c}\text { Total WP yang } \\
\text { Menyampaikan } \\
\text { SPT (orang) }\end{array}$ & $\begin{array}{c}\text { WP yang wajib } \\
\text { menyampaikan SPT } \\
\text { (orang) }\end{array}$ & $\begin{array}{c}\text { Total WP } \\
\text { terdaftar } \\
\text { (orang) }\end{array}$ \\
\hline 2013 & 62,50 & 9.033 .233 & 18.116 .000 & 19.410 .174 \\
\hline 2014 & 58,16 & 8.202 .309 & 14.101 .933 & 15.911 .576 \\
\hline 2015 & 54,15 & 5.413 .144 & 10.289 .590 & 15.911 .576 \\
\hline
\end{tabular}

Sumber :Ditjen Pajak, dan beberapa sumber diolah

Kepatuhan wajib pajak di Indonesia setiap tahun mengalami peningkatan seiring dengan bertambahnya jumlah wajib pajak. Pertambahan jumlah wajip pajak tidak berbanding lurus dengan peningkatan jumlah penerimaan pajak. Namun peningkatan realisasi kepatuhan pajak memberikan dampak positif terhadap target yang telah ditetapkan.

Dilain sisi, tingkat kepatuhan pembayaran pajak orang kaya sampai saat ini belum maksimal atau masih rendah, itu sebabnya upaya-upaya untuk menarik wajip pajak orang kaya terus dilakukan termasuk upaya Ditjen pajak membuat kantor pelayanan khusus bagi WP kaya atau High Net-Worth Individual (HNW). Kantor pelayanan pajak (KPP) WP BOP adalah salah satu kantor pelayanan yang berfungsi menjaring WP orang kaya terutama yang berada di Jakarta. KPP WP BOP akan melayani sekitar 1.200 orang kaya dengan kekayaan di atas Rp. 100 miliar.

Salah satu target kepatuhan yang perlu dilakukan juga adalah menjaring pajak yang berasal dari kekayaan yang berada di luar negri. Salah satu upayanya adalah membangkitkan kesadaran WP dan calon/mantan WP melalui pengampunan pajak (tax amnesty)

Rasio kepatuhan wajib pajak di Indonesia masih tergolong rendah jika dibandingkan dengan rasio di Negaranegara maju. Banyak factor yang menyebabkan rendahnya rasio tersebut, diantaranya : rendahnya tingkat kesadaran masyarakat dalam melaksanakan kewajiban penyetoran dan pelaporan pajak, minimnya jumlah fiskus atau pemeriksa pajak dan sebagainya.

\section{Penelitian terdahulu}

Hubungan tax amnesty dengan penerimaan pajak bahwa mengacu pada penelitian yang dilakukan oleh Ngadiman dan Huslin (2015) yang menunjukkan bahwa tax amnesty berpengaruh positif terhadap kepatuhan wajib pajak. Jika penerapan tax amnesty semakin tinggi, maka kepatuhan wajib pajak juga semakin tinggi. Berdasarkan uraian tersebut maka peneliti mengambil hipotesis pertama:

$H_{1}$ : tak amnesty berpengaruh positif terhadap penerimaan pajak.

Faktor lain yang berpengaruh terhadap penerimaan pajak adalah pertumbuhan ekonomi. Menurut Untoro (2010) pertumbuhan ekonomi adalah adalah perkembangan kegiatan dalam perekonomian yang menyebabkan barang dan jasa yang diproduksi dalam masyarakat bertambah dan kemakmuran masyarakat meningkat dalam jangka panjang. Jika kemakmuran penduduk meningkat maka akan $m$ engubah pola konsumsinya yang kemudian berpengaruh terhadap penerimaan pajak. Menurut Hanif (2010) jika pertumbuhan ekonomi suatu daerah meningkat, maka kemampuan masyarakat dalam membayar pajak (ability to pay) juga akan meningkat.

Hubungan pertumbuhan ekonomi dalam penerimaan pajak mengacu pada penelitian yang dilakukan oleh Triastuti (2015) yang menunjukkan bahwa pertumbuhan ekonomi berpengaruh signifikan terhadap penerimaan pajak. Jika pertumbuhan ekonomi semakin tinggi, maka pernerimaan pajak juga semakin tinggi. Berdasarkan uraian tersebut, maka peneliti mengambil hipotesis kedua: 
$\mathrm{H}_{2}$ : pertumbuhan ekonomi berpengaruh poisitif dan significant terhadap penerimaan pajak.

Faktor lain berpengaruh terhadap pada penerimaan pajak adalah kepatuhan wajib pajak. Menurut Torhler (2015) salah satu masalah yang paling serius bagi para pembuat keputusan kebijakan ekonomi adalah mendorong tingkat kepatuhan wajib pajak. Kepatuhan perpajakan sangat dibutuhkan untuk mengoptimalkan penerimaan pajak di Indonesia. Menurut Hasan (2010). Kepatuhan perpajakn dapat dikatakan sebagai tulang punggung dimana dibutuhkan suatu kerelaan dari wajib pajak itu sendiri untuk melaksanakan kewajibannya sehingga system tersebut dapat dilaksanakan dengan sebaik-baiknya.

Hubungan kepatuhan wajib pajak dengan penerimaan pajak mengacu pada penelitian Divianto (2013) yang menunjukkan bahwa kepatuhan wajib pajak berpengaruh signifikan terhadap penerimaan pajak. Jika kepatuhan wajib pajak semakin tinggi, maka penerimaan pajak juga semakin tinggi. Berdasarkan uraian tersebut, maka penlis mengambil hipotesis ketiga.

$H_{3}$ : kepatuhan wajib pajak berpengaruh positif dan signifikan terhadap penerimaan pajak.

Berdasarkan uraian tersebut di atas maka penulis mengambil hipotesis keempat $H_{4}$ : Tax amnesty pertumbuhan ekonomi, kepatuhan wajib pajak berpengaruh signifikan terhadap penerimaan pajak di Indonesia.

\section{METODE PENELITIAN}

Penelitian dilaksanakan di kantor pelayanan pajak pratama Pekanbaru Tampan rancangan penelitian menggunakan penelitian. Variabel bebas penelitian adalah tax amnesty. Pertumbuhan ekonomi, kepatuhan wajib pajak sedangkan variable terikat adalah penerimaan pajak. Populasi penelitian adalah wajib pajak orang pribadi yang terdaftar di KPP pratama pekanbaru Tampan sebanyak 47.528 orang. Pengambilan sampel menggunakan rumus Slovin (dalam Sugiyono, 2013) diperoleh jumlah minimal sampel wajib pajak orang pribadi terdaftar di KPP pratama tampan Pekanbaru sebanyak 100 orang. Metode pemilihan sampel menggunakan incidental sampling, yaitu siapa yang secara kebetulan bertemu dengan peneliti digunakan sebagai sampel serta cocok sebagai sumber data.

Tehnik pengumpulan data penelitian adalah kuesioner, skala yang digunakan dalam penyusunan kuesioner penelitian ini adalah skala likert, skala likert adalah skala yang digunakan untuk menyususn sikap, pendapat, dan persepsi seseorang atau sekelompok orang tentang fenomena social, setiap pernyataan disediakan 5 (lima) alternative jawaban yaitu : sangat setuju (SS), setuju (S), netral (N), tidak setuju (TS), dan sangat tidak setuju (STS). Analisis data yang digunakan dalam penelitian ini adalah (1) uji kualitas data yang terdiri dari uji validitas dan uji reabilitas, (2) Uji hipotesis menggunakan uji regresi linear berganda dengan uji asumsi klasik yang terdiri dari uji normalitas, uji multikolinearitas, uji heteroskedastisitas.

\section{HASIL DAN PEMBAHASAN \\ 4.1. Pengaruh Tax Amnesty terhadap penerimaan pajak}

Hasil pengujian hipotesis $H_{1}$ mengenai pengaruh tax amnesty terhadap penerimaan pajak menunjukkan nilai $t$ sebesar 3,267 dengan nilai signifikansi sebesar 0,002 oleh karena itu, hipotesis $H_{1}$ dalam penelitian ini diterima. Hal ini menunjukkan bahwa tax amnesty berpengaruh positif terhadap penerimaan pajak.

Hasil penelitian ini di dukung oleh penelitian terdahulu yang dilakukan oleh Ngadiman dan Huslin (2015) yang menunjukkan bahwa secara parsial tax amnesty berpengaruh positif dan signifikan terhadap kepatuhan wajib pajak. Penelitian lainnya dilakukan oleh Pratiwi (2016) yang menunjukkan bahwa secara parsial tax 
amnesty berpengaruh positif dan signifikan terhadap penerimaan pajak.

\subsection{Pengaruh pertumbuhan ekonomi terhadap penerimaan pajak}

Hasil pengujian hipotesis $\mathrm{H}_{2}$ mengenai pengaruh pertumbuhan ekonomi terhadap penerimaan pajak menunjukkan nilai $\mathrm{t}$ sebesar 2,315 dengan nilai signifikansi sebesar 0,023 , oleh karena itu hipotesis $\mathrm{H}_{2}$ dalam penelitian ini diterima. Hal ini menunjukkan bahwa pertumbuhan ekonomi berpengaruh positif dan signifikan terhadap penerimaan pajak.

Hasil penelitian ini didukung oleh penelitian terdahulu yang dilakukan oleh Triastuti (2015) yang menunjukkan bahwa secara parsial pertumbuhan ekonomi berpengaruh signifikan terhadap penerimaan pajak.

\subsection{Pengaruh kepatuhan wajib pajak terhadap penerimaan pajak}

Hasil pengujian hipotesis $H_{3}$ mengenai pengaruh kepatuhan wajib pajak terhadap penerimaan pajak menunjukkan nilai $\mathrm{t}$ sebesar 3,433 dengan nilai signifikansi sebesar 0,001 oleh karena itu hipotesis $\mathrm{H}_{3}$ dalam penelitian ini diterima. Hal ini menunjukkan bahwa kepatuhan wajib pajak berpengaruh positif dan signifikan terhadap penerimaan pajak.

Hasil penelitian ini didukung oleh penelitian terdahulu yang dilakukan oleh Divianto (2013) yang menunjukkan bahwa secara parsial kepatuhan wajib pajak orang pribadi berpengaruh signifikan terhadap penerimaan pajak penghasilan. Penelitian lainnya dilakukan oleh Sari (2012) yang menunjukkan bahwa secara parsial kepatuhan wajib pajak berpengaruh terhadap penerimaan penghasilan.

4.4. Pengaruh tax amnesty, pertumbuhan ekonomi, kepatuhan wajib pajak terhadap penerimaan pajak

Hasil pengujian hipotesis $\mathrm{H}_{4}$ mengenai Pengaruh tax amnesty, pertumbuhan ekonomi, kepatuhan wajib pajak terhadap penerimaan pajak menunjukkan nilai $\mathrm{F}$ sebesar 21,382 dengan nilai signifikansi sebesar 0,000 oleh karena itu hipotesis $H_{4}$ dalam penelitian ini diterima.

Tinggi rendahnya penerimaan pajak dapat dipengaruhi oleh beberapa factor. Factor yang sangat besar pengaruhnya pada penerimaan pajak adalah kepatuhan wajib pajak. Menurut Torgler (2015) salah satu masalah yang paling serius bagi para pembuat keputusan kebijakan ekonomi adalah mendorong tingkat kepatuhan wajib pajak. Kepatuhan perpajakan sangat di butuhkan untuk mengoptimalkan penerimaan pajak di Indonesia. Menurut Hasan (2008) kepatuhan perpajakan dapat dikatakan sebagai tulang punggung self assessment system dimana dibutuhkan suatu kerelaan dari wajib pajak itu sendiri untuk melaksanakan kewajibannya sehingga system tersebut dapat dilaksanakan dengan sebaik baiknya.

\section{PENUTUP}

\subsection{Kesimpulan}

Berdasarkan hasil penelitian maka dapat ditarik kesimpulan sebagai berikut:

1. Tax amnesty berpengaruh signifikan dan positif terhadp penerimaan pajak yang ditunjukkan dengan koefisien regresi yang positif 0,405 dengan nilai signifikansi uji t 0,002 lebih kecil dari $\alpha$ $=0,05$

2. Pertumbuhan ekonomi berpengaruh positif dan signifikan terhadap penerimaan pajak, yang ditunjukkan oleh koefisien regresi yang positif 0,312 dengan nilai signifikansi uji t 0,023 lebih kecil dari $\alpha=0,05$

3. Kepatuhan wajib pajak berpengaruh positif dan signifikan terhadap penerimaan pajak, yang ditunjukkan oleh koefisien regresiyang positif 0,361 dengan nilai signifikansi uji t 0,001 lebih kecil $\alpha=0,05$

4. Tax amnesty, pertumbuhan ekonomi, kepatuhan wajib pajak berpengaruh signifikan terhadap penerimaan pajak yang ditunjukkan dengan nilai signifikansi uji $\mathrm{F}$ 0,000 lebih kecil $\alpha=$ 0,05 . 


\subsection{Saran}

Saran yang dapat diberikan adalah

1. bagi manajemen KPP ptinyaratama Pekanbaru disarankan perlu adanya analisa dan tindak lanjut mengenai tax amnesty, pertumbuhan ekonomi, kepatuhan wajib pajak sangat lah penting dalam peningkatan penerimaan pajak sehingga pembangunan nasional dapat berjalan dengan baik

2. penerapan tax amnesty harus dilandasi dengan payung hukum yang berupa Undang-undang dan kejelasan syarat dan tujuannya

3. pemberian kebijakan pengampunan pajak semestinya tidak hanya menghapus hak tagih atas wajib pajak (WP) tetapi yang lebih penting lagi adalah memperbaiki kepatuhan WP, sehingga pada jangka panjang dapat meningkatkan penerimaan pajak.

\section{DAFTAR PUSTAKA}

Bohari. 2012. Pengantar Hukum Pajak. Jakarta: PT .Rajagrafindo Persada

Mardiasmo. 2016. Perpajakan Edisi Revisi 2016. Yogyakarta: CV.Andi Offset Pandiangan, Liberti. 2014. Administrasi Perpajakan. Jakarta: Erlangga Ratminto

Saidi, Muhammad Djafar. 2007. Pembaharuan Hukum Pajak Edisi Revisi.

Jakarta: PT.Rajagrafindo Persada Bandung Sugiyono. 2013. Metode Penelitian Bisnis. Bandung: CV Alfabeta

Soetopo, Hendyat. 2010. Perilaku Organisasi Bandung:

Rosda. Sugiyono. 2012. Metode penelitian kombinasi. Bandung: CV. Alfabeta Sugiyono.2013. 